Journal Universitas Muhammadiyah Gresik Engineering, Social Science, and Health International Conference (UMGESHIC)

UMGCINMATIC : $1^{\text {st }}$ Rethinking Education during Covid-19 Era: Challange and Innovation

\title{
THE EFFECT OF CONSUMER CONFIDENCE ON WORD OF MOUTH IN MAYBELLINE PRODUCTS
}

\author{
Author \\ Faizzatul Choiriyah$^{1}$, Asri Rejeki², Noer Suci Endah ${ }^{3}$ \\ 1,2,3Psychology Faculty, Universitas Muhammadiyah Gresik \\ Email: faizzatul_170701@umg.ac.id ${ }^{1}$ asrirejeki@umg.ac.id ${ }^{2}$, \\ nse.puspitaningrum@umg.ac.id ${ }^{3}$
}

\begin{abstract}
This study aims to determine the effect of consumer trust on word of mouth on Maybelline products. This study uses a quantitative approach using incidental sampling technique and gets 59 samples of students from the Accounting Study Program and Management Study Program. The method of collecting data on the Consumer Trust and Word of Mouth variables used a questionnaire compiled and modified by the researcher on a Likert scale. Test the validity of the scale using content validity. Scale reliability test using Alpha Cronbach technique. The results of data analysis using the Simple Linear Regression technique with the statistical program IBM SPSS Statistics 25, it is known that the value of R Square or the coefficient of determination is 0.403 from the consumer confidence variable, which means that the influence of consumer confidence on word of mouth is $16,3 \%$, while the rest is influenced by other variables. The results of the regression coefficient test show that in the Sig column the independent variables and constants have a significance level below 0.05 and this shows that there is an influence of consumer trust on word of mouth.
\end{abstract}

Keywords: Consumer Trust, Word of Mouth. 


\section{INTRODUCTION}

The buying and selling process cannot be separated from human life. Individuals in buying a product are faced with various considerations, causing them to try to find information related to the desired product. This information can be obtained from the internet, television advertisements, social media, and information from friends or family [1]

Conversations made by consumers about the experience of consuming a product without realizing it contains meaning that informs the product or service can be illustrated as free advertising for the product company. The reference brought by a product can be a positive image or a negative image according to experience. In addition, the image created in informal conversations has an impact on a product. The impact is that it can make the product more attractive to new consumers, but the opposite can also happen that new consumers are not interested in the product [2]

Loyal customer behavior can benefit the company in conditions of intense competition, this is called the word of mouth phenomenon. The phenomenon of word of mouth is believed to be able to encourage purchases by consumers, can influence the community, is efficient because it does not require a large budget (low cost), can create a positive picture of the product, and can touch consumer emotions). [3]

Kotler and Keller stated that word of mouth is a marketing activity through person-to-person intermediaries either orally, in writing, or through electronic communication tools connected to the internet based on experience with products or services. [4]

In general, we will trust what is conveyed by the closest people such as family or friends. Family or friends always suggest products that they think are good in terms of price, product quality, and product type. They continue to try to share their experiences using the product so that consumer confidence in the product increases. This is when word of mouth occurs. The results of research from Raniawati \& Totok (2017) state that the Madurese community carries out the word of mouth communication activities including in the good category (68.8\%) by discussing, promoting, and recommending Bangkalan batik to others [5].

Trust is a form of attitude that shows feelings of liking and continuing to use a product. According to Kotler, belief is a picture of the thoughts that a person follows about something. Basically, trust will arise if the product purchased is able to provide the benefits or values that consumers want. 7The results of research from Hakim \& Idris (2017) show that the perception of usefulness has a positive and significant impact on consumer confidence in Go-Ride consumers in the city of Bandung.

According to Mowen and Minor (2002:), "consumer beliefs (consumer beliefs) are all the knowledge and conclusions that consumers have in knowing products from objects, attributes, and benefits" [6].

Consumer trust is basically a form of consumer support for the efforts made to get everything 
they want, through consumer trust they will provide support related to the purchase decision that will be determined. Analysis of consumer confidence will provide an overview of all forms of activities carried out so that consumers really believe that the decision made is the best [7].

Consumer trust in a product or brand is necessary for business. This is due to the emergence of consumer trust so that prospective customers or customers will be interested in using a product offered by a company. With consumer trust, it is natural for other people to ask their opinion using the product and there will be other people who inform about the product. They will tell about the positive and negative aspects through word of mouth [8].

Trends Cosmetics in Indonesia brings up various types of cosmetics from many brands \& are available in various shopping centers. According to the Ministry of Industry (Kemenperin), it was recorded that in 2017 the national cosmetic industry grew 6.35\% and rose $7.36 \%$ in the first quarter of 2018. And also in 2016, the growth of the cosmetic industry market has grown by $7-8 \%$ in beauty care [9]

The rapidity of cosmetic products in the market affects a person's attitude towards the purchase and use of goods. Purchasing a cosmetic product is not just to fulfill a desire, but because cosmetics are a necessity. The use of cosmetics in Indonesia is growing rapidly. This is evident from the increasing consumption of cosmetics every year. This is reinforced by changes in people's lifestyles today. The trend of using cosmetics by men is a supporting factor for the increasing level of cosmetic consumption in Indonesia [2].

Based on the growth in the cosmetic industry, there are many choices for beauty products. There is a comparison of the number of cosmetic sales data explaining that the word "makeup" is a product that is always remembered in the minds of consumers. It is known that Wardah products occupy the top position with a percentage of $60.18 \%$, Maybelline ranks second at 44.34\%, Revlon 30.32\%, NYX 22.17\%, and Viva 21.27\% [9].

The researcher here takes the makeup product, Maybelline, because Maybelline ranks second which is the favorite from all walks of life, from the upper, middle, and lower classes. In addition, Maybelline has good quality and has various types of products with the latest innovations released by Maybelline. In addition, Maybelline products are easy to find all over the world. With unquestionable popularity

\section{METHODOLOGY}

The research method used was a quantitative method. This study used a non-probability sampling technique and the sampling technique used was incidental sampling in the Accounting Study Program and Management Study Program consisting of 59 people. Collecting data using a questionnaire with a Likert scale. The word of mouth scale used a modified word of mouth scale from Goyette's (2010) scale and a modified consumer confidence scale from the Andreas et, al (2008) bahar et., al (2013) scale. The data analysis technique used in this study was simple regression analysis and the statistical analysis process used in this study used the IBM statistical 
program for Social Science (SPSS) for windows version 25.

\section{RESULT AND DISCUSSION}

\begin{tabular}{lllllll}
\hline Variabel & $\mathrm{R}^{2}$ & $\mathrm{~F}$ & $\mathrm{Sig}$ & $\mathrm{Beta}$ & $\mathrm{t}$ & $\mathrm{Sig}$ \\
\hline $\begin{array}{l}\text { Constant } \\
\begin{array}{l}\text { Kepercayaan } \\
\text { Konsumen }\end{array}\end{array}$ & 0,163 & 11,077 & 0,002 & $0,838,1,991$ & 0,199 \\
\hline
\end{tabular}

a Dependent Variable: Word of Mouth

Based on the results of the correlation analysis that has been carried out, it is known that the correlation value (r) is 0.403 . This figure showed that consumer trust and word of mouth have a strong and positive relationship. The purpose of a positive relationship is that the higher consumer trust in Maybelline products, the higher the word of mouth on Maybelline products. And vice versa, the lower consumer confidence in Maybelline products then the lower the word of mouth on Maybelline products.

The results of the simple linear regression test showed that the $t$ value for the consumer confidence variable is 3.328 with $\mathrm{p}$ value $=0.002<0.05$. So this showed that consumer trust has a significant effect on word of mouth.

The influence of consumer trust on word of mouth is evidenced by the results of the analysis of the regression coefficient test data that there is a change in the regression coefficient of the influence of the $\mathrm{X}$ variable on the $\mathrm{Y}$ variable, the regression equation $\mathrm{Y}=35.336+0.838 \mathrm{X}$ which means the influence of the $\mathrm{X}$ variable (consumer trust) on changes in the $\mathrm{Y}$ variable. (word of mouth) is a positive effect through an increase or change in consumer confidence will be followed by an increase or change in word of mouth.

To find out how much the consumer trust variable affects the word of mouth variable on Maybelline products, it can be obtained from the results of the R Square value or the coefficient of determination of 0.403 or $16.3 \%$. This showed that the consumer trust variable affects word of mouth by $16.3 \%$. While the rest is influenced by other variables.

The findings obtained in this study are consumer trust is an attribute that contributes to doing word of mouth. This is in line with research from Rizanata (2014) which shows a significance value of 0.837 , which means that consumer trust affects word of mouth. Consumers say they trust direct recommendations from other consumers through word of mouth.

A high level of trust not only stimulates and fulfills consumers' high expectations in transaction satisfaction but also eliminates uncertainty, consumer risk, and interdependence. The higher the level of consumer trust, the higher the level of consumer purchase intention and word of mouth, and it is easier for companies to retain consumers [15].

Consumer trust in a product or brand is necessary for business. This is due to the emergence of consumer trust so that prospective customers or customers will be interested in using a product 
offered by a company. With consumer trust, it is natural for other people to ask their opinion using the product and there will be other people who inform about the product. They will tell about the positive and negative aspects through word of mouth.

\section{CONCLUSION AND LIMITATION}

Based on the results of the research, the results of the regression test showed that there was an influence of consumer trust on word of mouth on Maybelline products. The results of the $r$ square show a number of $16.3 \%$. This showed that the consumer trust variable affects word of mouth by $16.3 \%$. While the rest is influenced by other variables.

Based on the research process carried out by the researcher, there were several limitations that were encountered and could be taken into consideration in further studies that wish to conduct research on the same variables in this study. The following are the limitations in this study, among others the number of respondents in this study was only 59 subjects, so this is a lack of research to describe the real situation.

\section{REFERENCES}

A. Thariq, "word of mouth: dahulu, kini, dan nanti," psikobuletin: buletin ilmiah psikologi, pp. 196-197, 2020.

Fahira, sarah, t. Hartati and h. Amir, "pengaruh citra merek dan harga diri terhadap keputusan pembelian maskara maybelline (studi kasus pada mahasiswa administrasi niaga politeknik negeri jakarta)," epigrem, 2019.

I. A, rohman and noermijati, "analisis pengaruh kualitas produk dan strategi harga terhadap kepuasan pelanggan, dan pengaruhnya pada terbentuknya word of mouth di perumahan madani group jabodetabek," jurnal aplikasi manajemen, p. 86, 2013.

K. Joesyiana, "pengaruh word of mouth terhadap keputusan pembelian konsumen pada media online shop shopee di pekanbaru," valuta, p. 72, 2018.

Raniawati and t. W. Abadi, "komunikasi word of mouth dan keputusan pembelian batik bangkalan," jurnal aspikom, p. 289, 2017.

W. B. Prasetyo, "pengaruh kualitas pelayanan, kepercayaan dan kepuasan terhadap loyalitas pelanggan ( studi pada swalayan luwes purwodadi)," jurnal manajemen dan bisnis, 2013.

A. Sugara and r. Y. Dewantara, "analisis kepercayaan dan keputusan terhadap penggunaan sistem transaksi jual beli online ( studi pada konsumen "z")," jurnal administrasi bisnis , p. 9 , 2017.

M. F. Rizanata, "pengaruh kepercayaan pelanggan terhadap word of mouth niat beli dan retensi pelangan gerai indomaret di surabaya," journal of business and bangking, p. 37, 2014.

Reni and tri, "pengaruh beauty vlogger review dan kualitas produk terhadap keputusan pembelian (studi pada kosmetik maybelline di surabaya)," jurnal pendidikan tata niaga, pp. 716-722, 2020.

Rahma and wiwaha, "pengaruh word of mouth dan brand image terhadap keputusan 
penggunaan salon kecantikan pada konsumen miloff beauty bar," jurnal ilmiah widya ekonomika, pp. 134-140, 2017.

I. Goyette, 1. Ricard, j. Bergeron and f. Marticotte, "e-wom scale: word of mouth measurement scale for e-services context," canadian journal of administrative sciences, pp. 5-16, 2010.

S. Dwi and koeshartono, "pengaruh kepercayaan konsumen terhadap loyalitas konsumen dengan switching cost sebagai variabel mediasi," jurnal ekonomi, p. 15, 2006.

Anang and rizky, "analisis kepercayaan dan kepuasan terhadap penggunaan sistem transaksi jual beli online (studi pada konsumen'z')," jurnal ekonomi, p. 9, 2017.

M. Bahrudin and s. Zuhro, "pengaruh kepercayaan dan kepuasan pelanggan terhadap loyalitas pelanggan," jurnal bisnis dan manajemen islam , p. 6, 2015.

Chen and barnes, "initial trust and pnline buyer behaviour," journal of industrial management \& data systems, pp. 21-36, 2007.

V. Susanti and c. Hadi, "kepercayaan konsumen dalam melakukan pembelian gadget secara online," jurnal psikologi industri dan organisasi, p. 02, 2013. 